\title{
Triassic age of the continental Pular Formation, Sierra de Almeida, Antofagasta, northern Chile
}

\section{Hans Niemeyer ${ }^{1}$, Ana María Zavattieri², Sara Ballent ${ }^{3}$, Alba Zamuner ${ }^{4}$, Oscar Gallego ${ }^{5}$}

I Departamento de Ciencias Geológicas, Facultad de Ingeniería y Ciencias Geológicas, Universidad Católica del Norte, Avda. Angamos 0610, Antofagasta, Chile.

hansn@ucn.cl

2 Instituto Argentino de Nivologia, Glaciología y Ciencias Ambientales (IANIGLA, CRICYT-CONICET), Mendoza, Argentina. amz@lab.cricyt.edu.ar

3 CONICET, División Paleontología de Invertebrados, Facultad de Ciencias Naturales y Museo, Universidad Nacional de La Plata, Paseo del Bosque s/n, 1900 La Plata, Argentina. sballent@fcnym.unlp.edu.ar

${ }_{4}$ CONICET, División Paleobotánica, Facultad de Ciencias Naturales y Museo, Universidad Nacional de La Plata, Paseo del Bosque s/n, 1900 La Plata, Argentina.

azamuer@fcnym.unlp.edu.ar

5 FACENA-UNNE, Departamento de Biología, Paleontología y CONICET, Area de Paleontología, Centro de Ecología Aplicada del Litoral, Corrientes, Argentina.

ofgallego@hotmail.com

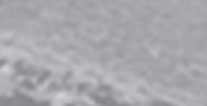




\title{
Triassic age of the continental Pular Formation, Sierra de Almeida, Antofagasta, northern Chile
}

\author{
Hans Niemeyer'1, Ana María Zavattieri², Sara Ballent ${ }^{3}$, Alba Zamuner ${ }^{4}$, Oscar Gallego ${ }^{5}$ \\ ${ }^{1}$ Departamento de Ciencias Geológicas, Facultad de Ingeniería y Ciencias Geológicas, Universidad Católica del Norte, Avda. \\ Angamos 0610, Antofagasta, Chile. \\ hansn@ucn.cl \\ 2 Instituto Argentino de Nivología, Glaciología y Ciencias Ambientales (IANIGLA, CRICYT-CONICET), Mendoza, Argentina. \\ amz@lab.cricyt.edu.ar \\ ${ }_{3}$ CONICET, División Paleontología de Invertebrados, Facultad de Ciencias Naturales y Museo, Universidad Nacional de La Plata, \\ Paseo del Bosque s/n, 1900 La Plata, Argentina. \\ sballent@fcnym.unlp.edu.ar \\ ${ }^{4}$ CONICET, División Paleobotánica, Facultad de Ciencias Naturales y Museo, Universidad Nacional de La Plata, Paseo del Bosque \\ s/n, 1900 La Plata, Argentina. \\ azamuer@fcnym.unlp.edu.ar \\ ${ }_{5}$ FACENA-UNNE, Departamento de Biología, Paleontología y CONICET, Área de Paleontología, Centro de Ecología Aplicada del \\ Litoral, Corrientes, Argentina. \\ ofgallego@hotmail.com
}

\begin{abstract}
In this contribution, we present a reassessment of the Pular Formation age (Sierra de Almeida, Antofagasta) that in previous papers was attributed to either the Late Paleozoic or Triassic. At Quebrada del Medio, the Pular Formation includes a 379-meter-thick stratigraphic section formed from base to top by conglomerates, sandstones, black bituminous shales and limestones, tuffaceous sandstones and a poorly welded ignimbrite that accumulated in fluvial and lacustrine environments. A multidisciplinary study of the flora and fauna was undertaken. The existence of diagnostic Gondwana microflora and macroflora allows attributing a Middle Triassic to early Late Triassic age to the Pular Formation.
\end{abstract}

Keywords: Pular Formation, Triassic, Gondwana flora, Fluvial and lacustrine environments, Chile.

RESUMEN. Edad triásica de la Formación Pular de ambiente continental, Sierra de Almeida, Antofagasta, Norte de Chile. En esta contribución se presentan nuevos antecedentes acerca de la edad de la Formación Pular (Sierra de Almeida, Región de Antofagasta) que, en trabajos previos, ha sido atribuida tanto al Paleozoico Superior como al Triásico. En la Quebrada del Medio, la formación incluye una sección estratigráfica de $379 \mathrm{~m}$ de espesor constituida, de base a techo, por conglomerados, areniscas, lutitas negras bituminosas, calizas y areniscas tobáceas que, culminando con un nivel de ignimbritas pobremente soldado, se acumularon en ambientes fluvial y lacustre. Se efectúa un estudio multidisciplinario de la flora y la fauna. La existencia de micro y macroflora diagnóstica de Gondwana permite establecer que la Formación Pular se depositó entre el Triásico Medio y el Triásico Tardío temprano. 


\section{Introduction}

In the areas of the Atacama and Punta Negra Salars in the Antofagasta Region of northern Chile a thick succession of pre-Jurassic volcanic and volcaniclastic rocks crops out. Here, interbeds of limnic beds can be observed (Pichowiak et al., 1987). Some of these interbeds are fossiliferous allowing a chronological assignment, correlations with neighbouring formations and paleogeographic reconstructions (Breitkreuz and Zeil, 1994). They mainly belong to the Middle Member of the Tuina Formation (Raczynsky, 1963), El Bordo

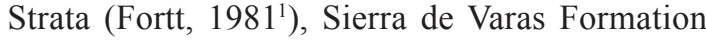
(Marinovic et al., 1995), Middle Member of the Peine Formation (Breitkreuz, 1991) and the Pular Formation (Brüggen, 1942) (Fig. 1).

It was assumed that all these interbeds would show the same stratigraphic position and thus represent a single lacustrine depositional event that developed during the Late CarboniferousEarly Permian (Bahlburg and Breitkreuz, 1991; Breitkreuz et al., 1992). Nevertheless, much care should be taken in correlating them, since they could represent lacustrine events that would have occurred at different times. Taking into account the considerable degree of confusion in the chronological assignment of these units, we suggest in this paper that a partial revision of the ages and sedimentary environments, including the contact

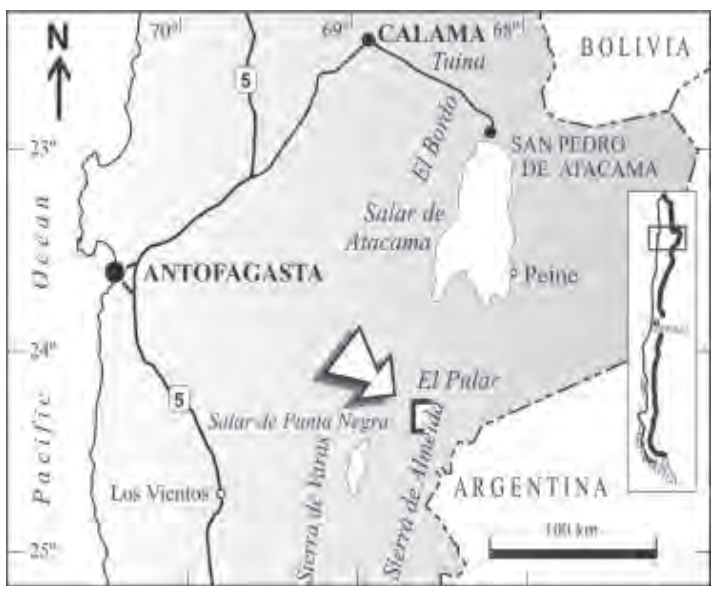

FIG. 1. Geographic location of the Pular Formation, Sierra de Almeida, Antofagasta Region, northern Chile. The locations for Tuina, El Bordo, Sierra de Varas and Peine formations are also shown. relationships of each of them before any attempt to correlate them, should be done.

This multidisciplinary study includes a revision of the stratigraphical and paleontological analyses on microflora, macroflora, conchostracans and calcareous microfauna of the Pular Formation that crops out in the Sierra de Almeida (Fig. 1) and that was studied at Quebrada del Medio, a tributary of Quebrada Pajonales (Fig. 2).

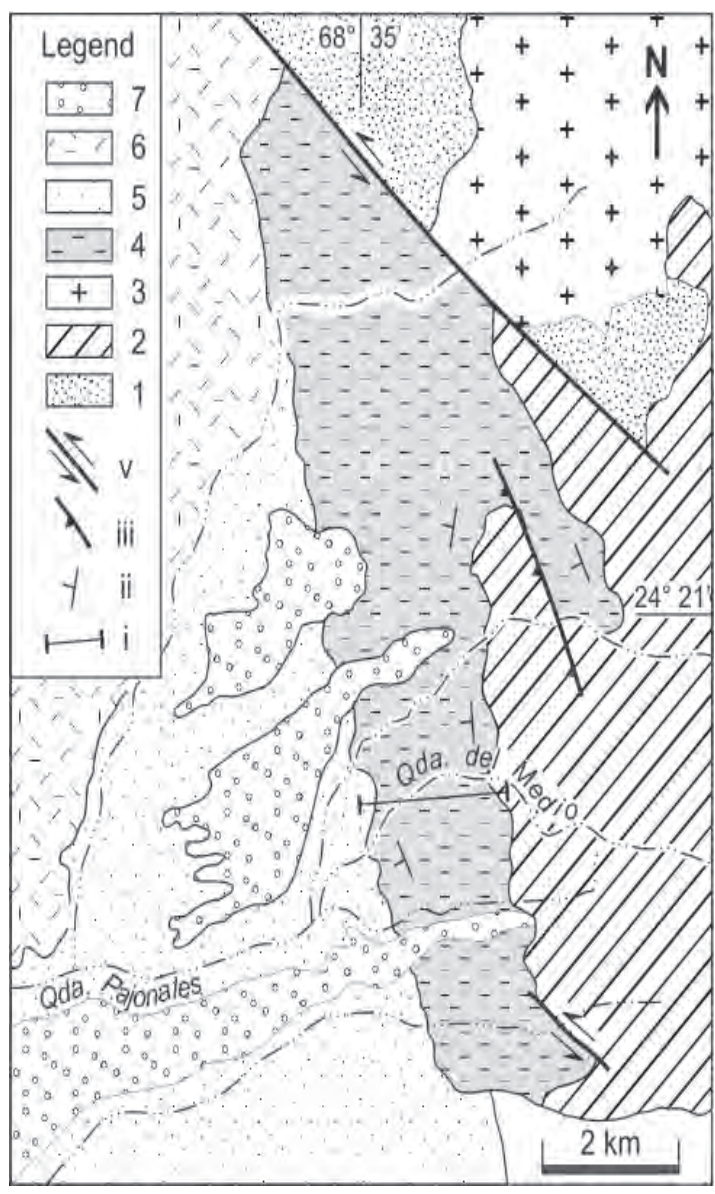

FIG. 2. Geological sketch of the Pular Formation, modified from Osorio and Rivano (1985). 1.Zorritas Formation: cuarzoarenites (Devonian - Early Carboniferous); 2. La Tabla Formation: andesitic and acid volcanites (Late Paleozoic); 3. Granitoids (Late Paleozoic); 4. Pular Formation: sandstones, conglomerates, bituminous shales, and ignimbrites (Middle to early Late Triassic); 5. Pajonales Formation: red-beds of sandstones and conglomerates (Maastrichtian); 6. Basalts (Cenozoic); 7. Gravels (Cenozoic). i. Stratigraphic section (this work); ii. Stratification attitude; iii. Reverse fault; v. Transcurrent fault.

1981. Geología general de los Cuadrángulos Cerro Químal, Laguna Tebinquiche, Llano de la Paciencia y Salar de Atacama, II Región, escala

1:100.000. Instituto de Investigaciones Geológicas (Unpublished), 48 p. Santiago, Chile. 


\section{Stratigraphy}

\subsection{Stratigraphic section}

The 379 m thick Pular Formation overlies with an erosive contact the Late Carboniferous-Early Permian La Tabla Formation and underlies with a pseudoconcordant contact the Maastrichtian Pajonales Formation. This succession is well exposed at Quebrada del Medio (Fig. 3). It includes a thinning and fining upward sedimentary succession in its lower third (units I-III). Unit IV is a volcanic-rich sandstone layer, and Unit V, an ignimbrite. A description of the different units, from base to top is as follows:

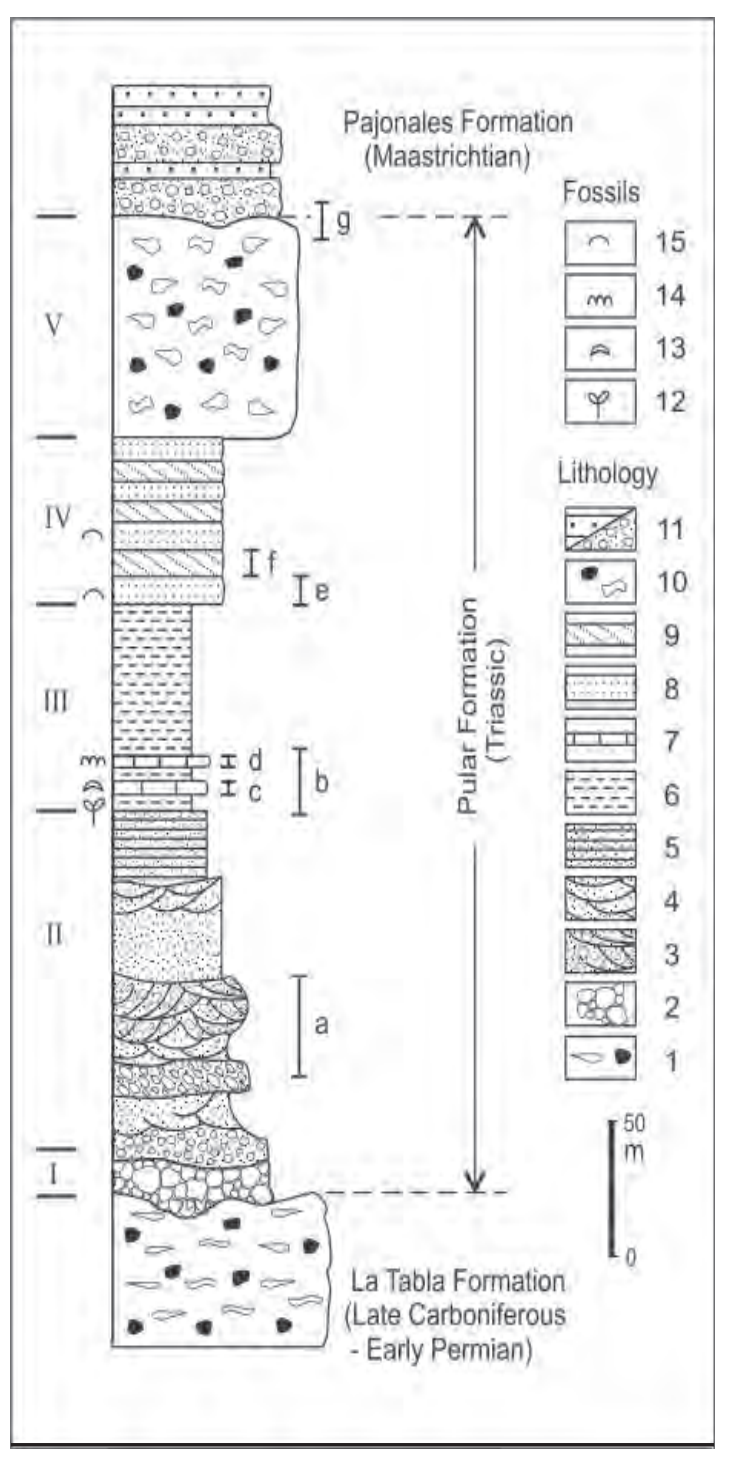

\subsubsection{Unit I}

$20 \mathrm{~m}$ of coarse, purple, clast-supported, conglomerate with clasts $2-50 \mathrm{~cm}$ in diameter composed of rhyolite, rhyolitic tuffs and andesite in a scarce matrix of coarse-grained sandstone. The larger clasts, of up to $50 \mathrm{~cm}$ in diameter, consist of brown to yellow fragmental welded ignimbrite derived from the La Tabla Formation (Carboniferous-Permian; Gardeweg et al., 1994), which immediately underlies the conglomerates of Unit I with an erosive contact. The definition of this conglomerate as the base of the Pular Formation agrees with that given by Covacevich et al. (1988).

\subsubsection{Unit II}

$140 \mathrm{~m}$ of up to $30 \mathrm{~m}$ thick tabular bodies of matrix-supported conglomerates (Fig. 4a), with trough cross-stratification, organized in at least, three fining-up cycles. They are composed of well rounded to subrounded clasts, up to $20 \mathrm{~cm}$ in diameter, embedded in a coarse-grained green sandstone matrix. The base of the conglomerate bodies (one of them showing imbricated clasts) is erosive and irregular and they grade upwards to coarse-grained sandstones and, near the top of the unit, to thin parallel beds up to $20-30 \mathrm{~cm}$ thick of yellow to light gray medium fine-grained sandstones.

\subsubsection{Unit III}

$76 \mathrm{~m}$ of well-bedded (laminated) and indurated black bituminous shales (Fig. 4b) including two 20centimeter-thick limestone intercalations hosting ostracod fauna (Fig. 4c) and stromatolitic algae (Fig 4d). Upper levels contain carbonaceous shales with fossil plant remains (Pseudoctenis fissa, see Age and fossiliferous content paragraph).

FIG. 3. Stratigraphic section of the Pular Formation. Roman numbers I to V show the units in which the Pular Formation was divided at Quebrada del Medio. The different units are described in the text. Lithology: 1. Fragmental welded ignimbrite; 2. Clast-supported conglomerates; 3 . Matrixsupported conglomerates with trough cross-bedding; 4. Sandstones with cross-stratification; 5. Fine-grained sandstones with thin parallel-bedding; 6. Well-laminated black bituminous shales; 7. Limestones; 8 . Well-stratified tuffaceous sandstones; 9. Tuffaceous sandstones with high-angle cross-bedding; 10. Fragmental, poorly welded, massive ignimbrite; 11. Red-beds: sandstones and conglomerates; 12. Fossil plants; 13. Fossil ostracods; 14. Fossil stromatolites; 15. Fossil conchostracans. a-g: Locations of beds represented in the photographs of figure 4 . 


\subsubsection{Unit IV}

$62 \mathrm{~m}$ of well-stratified tuffaceous sandstones (15-30 centimeter-thick beds) alternating with coarse-grained, 30 centimeter-thick, strata of red sandstones (Fig. 4e), some of which show high angle cross-bedding (Fig. 4f). Two levels carrying abundant conchostracans occur near the base.

\subsubsection{Unit $V$}

81 m of whitish-pink, fragmental, poorly welded, massive ignimbrite unconformably covered by red beds of the Pajonales Formation (Maastrichtian; Salinas et al., 1991) (Fig. 4g).

\subsection{Definition and contact relationships}

The Pular Formation was first defined by Brüggen (1942) who named it as 'Pizarras betuminosas del Pular' and stated that it was a lenticular succession between a thick series of red sandstones (actually the Maastrichtian Pajonales Formation of Salinas et al., 1991) on its top, and porphyric and andesitic breccias of the 'Formación Porfirítica' (actually the Late Carboniferous-Early Permian La Tabla Formation of Gardeweg et al., 1994) on its bottom.

Brüggen (1942) indicated that this formation overlies a volcanic sequence ('Formación Porfirítica') composed of green, violet and brown andesitic rocks. Later on he argued that 'the bituminous series seems to have been deposited in a landscape depression between the porphyritic hills' (Brüggen, 1950, p.103). The same criterion was adopted thereafter by Harrington (1961).

The volcanic rocks of Brüggen's 'Formación Porfirítica' (1942) were mapped by Davidson et al. (1981) who assigned to them a possible Triassic age. These rocks, in turn, overlie the 'Volcanitas Ácidas de Sierra San Juan' (Davidson et al., 1981) composed mainly of rhyolitic lavas and tuffs. An ignimbritic flow of the latter was dated (K-Ar in biotite) in 290 \pm 7 Ma (Carboniferous-Permian boundary) (Davidson et al., 1985; Gardeweg et al., 1994). The 'Volcanitas ácidas de Sierra San Juan' were later included within the La Tabla Formation by Gardeweg et al. (1994) which was attributed to the Carboniferous-Permian. At the same time, the Pular Formation was also included by these authors within the La Tabla Formation. In this study, we consider that the 'Formación Porfirítica' forms the upper part of the La Tabla Formation. Finally, the andesitic and acidic volcanic sequence of the La Tabla Formation is intruded by a Permian granitoid of $285 \pm 4$ whole rock Rb-Sr age (Brook et al., 1986 in Gardeweg et al., 1994), which is concordant, within its analytical error, with the age of the ignimbritic flow cited above. Consequently, the paraconcordant contact relationships show the existence of two different successions: 1. the La Tabla Formation of Late Paleozoic age below and 2. the Pular Formation, whose age should be younger than the La Tabla Formation, above.

\section{Age and fossiliferous content}

A Late Cretaceous age was first attributed to the Pular Formation by Brüggen (1950) based on a correlation with the Puca Formation in Argentina and Bolivia, whereas Harrington (1961) goes further in the precision of the Cretaceous age and suggests a Tithonian-Barremian age based on the presence of Cyzicus sp. Davidson et al. (1981) suggested a Triassic age for the Pular Formation based on poorly preserved plant fossil remains. Nevertheless, Osorio and Rivano (1985) attributed an Early Carboniferous age to this formation on the basis of determinations of ostracods. Covacevich et al. (1988) also assumed a Paleozoic age for this formation. Finally, Chong et al. (1997) found Triassic plant remains in outcrops that can be assigned to the Pular Formation. These controversial chronological assignments for the $\mathrm{Pu}$ lar Formation induced the present review. The age of the Pular Formation was reassessed through the study of the microflora (A.M.Z.), macroflora (A.Z.), conchostracans (O.G.) and calcareous microfauna (S.B.) collected by H.N.

\subsection{Palynomorphs}

A pollen assemblage was collected from the middle part of the Pular Formation which is composed of scarce spores and pollen grains. Most palynomorphs are too poorly preserved for taxonomic identification. Nevertheless, some of the forms recognized could be assessed as: Deltoidospora sp. (Plate 1a), cf. Dictyophyllidites sp., Granulatisporites sp. (Plate 1b), Gleicheniidites sp. (Plate 1c), cf. Osmundacidites sp., cf. Alisporites parvus de Jersey (Plate 1d), cf. Pinuspollenites sp. (Plate 1e), Alisporites sp. cf. A. lowoodensis de Jersey (Plate 1f), Alisporites sp. cf. A. australis de Jersey (Plate 1g), Alisporites sp., cf. Klausipollenites sp. (Plate 

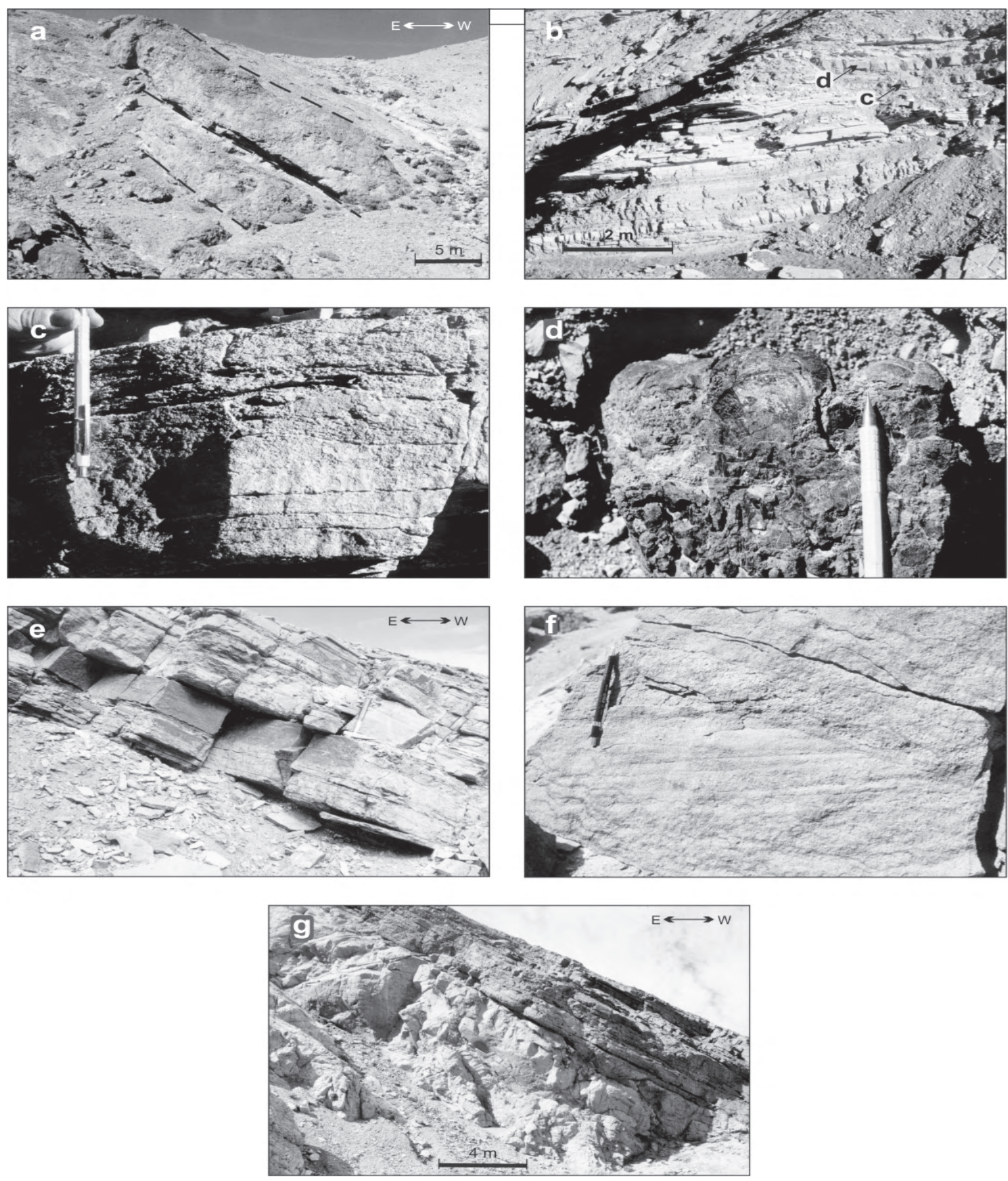

FIG. 4. Various lithologic facies of the Pular Formation. The location of the figures a-g are shown in figure 3. The point of the pencil in $\mathbf{c}, \mathbf{d}$ and $\mathbf{f}$ shows the top of the succession. a. Two conglomeratic tabular bodies from the middle part of Unit II; $\mathbf{b}$. Bituminous shales interstratified with two limestone beds at the base of Unit III. Location of beds $\mathrm{c}$ and $\mathrm{d}$ are shown; $\mathbf{c}$. Well-stratified limestone, coquina of calcareous microfossils at the base of Unit III, shown in b; d. Silicified stromatolites in a limestone from the base of Unit III, shown in b; e. Well-laminated tuffaceous sandstones with conchostracans; f. Coarse-grained sandstone with cross-bedding at the base of Unit IV; $\mathbf{g}$. White pinkish fragmental ignimbrite of Unit V in contact with the basal conglomerate of the Pajonales Formation (Maastrichtian). 
1h), Minutosaccus sp., cf. Stereisporites sp., cf. Vitreisporites $\mathrm{sp}$. and only one polyplicate pollen grain undoubtedly assignable to Equisetosporites sp. cf. E. cacheutensis Jain (Plate 1i).

The following data suggest a Late Triassic age, instead of Late Paleozoic as previously assigned to the Pular Formation by some authors: 1. the occurrence of a common proportion of haploxylonoid to slightly diploxylonoid pollen grains (Alisporitesassemblages); 2. very rare striate bisaccate pollen grains (which is a dominating element in Upper Paleozoic microfloras); 3. trilete spores of bryophytes (Stereisporites) and pteridophytic affinities such as the osmundacean (Osmundacidites, Granulatisporites), Gleicheniaceae (Gleicheniidites), Dipteridaceae-Matoniaceae (Dictyophyllidites, Deltoidospora), and Dicksoniaceae-Cyatheaceae (Deltoidospora) and, primarily, 4. the presence of the species Equisetosporites sp. cf. E. cacheutensis Jain. The Gondwanean records of this last polyplicate gnetalean pollen range from Early to Late Triassic (de Jersey and Raine, 1990). Similarly, gymnospermous pollen grains assigned to cf. Klausipollenites $\mathrm{sp}$. and cf. Minutosaccus $\mathrm{sp}$. associated with the typical Triassic Corystosperms affinity (Alisporites-type) constitute common components of Late Triassic microfloras of Argentina and of other age-equivalent gondwanean assemblages (Zavattieri and Batten, 1996). All mentioned genera of bryophytic and pteridophytic spores and gymnospermous pollen grains have also been previously recorded in the early Late Triassic assemblages of the Llafquentué-Huimpil Formation (Askin et al., 1981) and from the Panguipulli Formation (Zavattieri et al., 2003) in southern Chile.

\subsection{Plant remains}

The assignment of the Triassic age to the Pular Formation, based on the new findings of palynomorphs, is consistent with the record of plant megafossil remains. The plant specimen collected during this study represents a Cycad frond belonging to Pseudoctenis fissa Du Toit, 1927 (Plate 2a). This taxon is a common component in the Triassic of Gondwana. In Argentina it has been reported for the Barreal Formation (Bonetti, 1968) and Laguna Colorada Formation (Gnaedinger and Herbst, 1997); in South Africa it was cited for the Molteno Formation (Du Toit, 1927; Anderson and
Anderson, 1985; Anderson and Anderson, 1989) and in Australia it was reported for the Subregion Ipswich, Bryden and Esk Formations (Anderson and Anderson, 1989). Chong et al. (1997) also reported other diagnostic taxa agreeing with this age for the Pular Formation: Kurtziana cacheutensis (Kurtz) Frenguelli, 1942 from the late Middle TriassicEarly Jurassic, Dicroidium odontopteroides var. odontopteroides (Morris) Gothan, 1912 from the Late Triassic, Zuberia papillata (Townrow) Artabe, 1990 from the Early Triassic-late Middle Triassic, Zuberia feistmantelii (Johnson) Frenguelli, 1943 from the Early Triassic-late Middle Triassic, Tranquiloxylon sp. from the late Middle Triassic, Heidiphyllum elongatum (Morris) Retallack, 1981 from the Middle Triassic-Early Jurassic.

\subsection{Conchostracans}

Fossils described in this study were assigned to the species Euestheria forbesi Jones (in Raymond, 1946) (Plate 2, b-e). This species has a short biochron ranging from the Middle Triassic (Upper Ladinian) to the early Late Triassic (Middle Carnian). E. forbesi has been reported from different localities in the Triassic strata from both the southern (Argentina, Brazil, Africa) and northern (Greenland and France) hemispheres (Gallego, 1999, 2001a, b). This is the first record of E. forbesi in the Triassic of Chile extending its paleogeographic distribution in southern South America. It has only been previously reported for the Triassic basins of central-western Argentina: Cuyana Basin (Cacheuta, Potrerillos and probably Cerro de Las Cabras Formations), Barreal-Calingasta Basin (Cortaderita Formation) and Bermejo Basin (Los Rastros and Ischichuca formations) and also it has been recorded in the Santa Maria Formation of southern Brazil (Gallego, 2001a, b).

\subsection{Calcareous microfauna}

It consists of non-marine ostracods (Crustacea) and rare green algae (Charophyta). The ostracods are mostly represented by Volganella $\mathrm{sp}$. This species has been well described and illustrated by Osorio and Rivano (1985) as Chamishaella? sp., a marine Paraparchitidae. We think this species is best included in Volganella Sharapova and Mandelstam, a large (more than $2 \mathrm{~mm}$ in length) fresh 
water ostracod known, up to the present, from the Permian of the ex USSR. Ostracod collection levels for this study are the same as those examined by Osorio and Rivano (1985). For the present study, it is worth mentioning that Volganella sp. juveniles closely resemble a species referred to as Cultella sp. by Chaia (pers. comm., 1992) which occurs in the upper part of the Cerro de Las Cabras Formation (late Middle Triassic) from Quebrada del Arbolito, in the Quebrada de San Isidro, in the Precordillera west of Mendoza, Argentina (Hünicken and Chaia, 1992). Even though the ostracods recognized in this paper cannot be dated, they are good indicators of fresh water paleoenvironmental conditions.

\section{Depositional environment}

The depositional environment of the Pular Formation is inferred on the basis of the succession of facies shown in figure 3 and on its fossiliferous content. The conglomerates and sandstones from the base of the Pular Formation (Units I-II) represent a fining-up sequence that probably was deposited in a distal part of a braided river environment (Miall, 1977), while the bituminous shales and limestones from Unit III were formed in a quiet lacustrine fresh-water domain. Osorio and Rivano (1985) inferred instead a lagoonal environment with brackish water in connection with the sea for this part of the formation. Nevertheless, palynofacies and geochemical analysis reported by Wood et al. (2002) on bituminous shale samples of the Pular Formation show that they are typical oil-prone Type I lacustrine deposits. These deposits may have formed under a low energy regime because both adult and juvenile fresh-water ostracods were found together. Charophyta are algae thought to be intolerant of high salinity and therefore good indicators of fresh water conditions and Cyanobacteria form stromatolites in shallow (less than $10 \mathrm{~m}$ ) lake waters (Nichols, 1999). Black shales in Unit III indicate limited oxygen supply to the limnic sediments and thus favor the preservation of organic matter, suggesting a warm climate with small seasonal variations (Einsele, 1992). The upper part of the section (Unit IV), including sandstones with high-angle cross-bedding, represents deposits of medium energy flood-plain environment (Reineck and Singh, 1980; see for example their stratigraphic section in figure 430) influenced by volcanic ash de- position. Also the presence of conchostracan fresh water fauna in this unit suggest this environment. Ignimbrite (Unit V) at the top of the section shows the occurrence of important volcanic activity at the end of sediment accumulation.

\section{Discussion}

Data on ostracods has not been well managed as chronological indicators for the limnic levels around the Atacama and Punta Negra Salars. In fact, recent geochronological $\mathrm{K}-\mathrm{Ar}$ data by Basso and Marinovic (2003) allow determining that the age of the El Bordo Formation is Triassic and not Paleozoic as was previously stated based on ostracods described by Fortt $\left(1982^{2}\right)$ and whose Paleozoic age was suggested by Osorio in Marinovic and Lahsen (1984).

Contact relationships, together with multidisciplinary biochronological studies are of primary importance in assessing the correct succession of events in these type of sequences. In the case of the El Bordo Formation, an angular unconformity separates this unit from Carboniferous-Permian volcanic rocks (Basso and Marinovic, 2003) suggesting that this formation is younger than Paleozoic. In the case of the Pular Formation, a good geological appraisal allowed stating that this formation is very different in lithological appearance and younger than the 'Formación Porfirítica' as Brüggen observed in 1942. On the other hand, considering the geological context of the Sierra de Varas Formation, even if its plant remains show a biochron that spans in time from the Upper Paleozoic to the Triassic (Covacevich, Osorio in Marinovic et al., 1995), the age of this formation cannot be Triassic simply because it is intruded by a well dated Carboniferous granite (Smoje and Marinovic, 1994). Consequently, any correlation with the Pular Formation is fallacious (Marinovic et al., 1995).

The idea of intra-arc basins developed in a Late Paleozoic volcanic arc in northern Chile as stated by Breitkreuz and Zeil (1994) is still valid. Limnic deposits of different ages have been discussed here. Some of them accumulated in the Paleozoic intra-arc basins, but others in Triassic rift-basins. In fact, when the Late Paleozoic-Triassic boundary is trespassed, the tectonic setting changes dramatically from an active continental margin with a nearly north-south trending arc development in the 1982. Estudio de Ostrácodos de la Formación El Bordo, Región de Antofagasta, Chile. Curso Proyecto III. Universidad de Chile, Departamento de
Geología y Geofísica (Unpublished), 38 p. Santiago, Chile. 
Late Paleozoic to an intra-continental rift system of northwest orientation in the Triassic (Charrier, 1979). The significance of this statement is that a completely different paleogeography of the continental deposits under consideration and also the tectonic character of the associated volcanism were produced.

\section{Conclusions}

The conclusions of this study are: $\mathbf{1}$. The Pular Formation can be assigned to the Middle Triassic to early Late Triassic according to new paleontological records of microflora, macroflora and conchostracans. The ostracods do not represent a diagnostic chronological group on which the age of this formation can be based; 2. A continental depositional environment is confirmed for the Pular Formation on the basis of sedimentological and paleontological arguments. In fact, the thinning and fining upward succession of the lower third of it shows a transitional environment from high energy fluvial to lacustrine conditions. The inferred lacustrine conditions are based on the palynomorph assemblages and on the presence of fresh-water invertebrates. The upper part of the succession was deposited in a medium energy floodplain environment with strong supply of volcanic ash, which is the evidence of volcanic activity that culminates with an ignimbrite; 3. Care should be taken in correlating the limnic formations around the Atacama and Punta Negra Salars as they would be assigned to different ages and tectonic settings.

\section{Acknowledgements}

The authors thank R. Herbst (INSUGEO-CONICET, San Miguel de Tucumán, Argentina), S. Palma (Universidad de Concepción, Chile), N. Blanco, E. Pérez and M. Suárez (Servicio Nacional de Geología y Minería, Chile) for their reviews of this paper. The drawings were made by L. Jofré (Universidad Católica del Norte, Antofagasta, Chile). M.E. Soler (IANIGLA, Mendoza, Argentina) helped with the English version.

\section{References}

Anderson, J.M.; Anderson. H. 1985. Paleoflora of Southern Africa. Prodromus of South African Megafloras Devonian to Lower Cretaceous. A.A. Balkema: 421 p. Rotterdam.

Anderson, J.M.; Anderson, H. 1989. Paleoflora of Southern Africa, Molteno Formation (Triassic). Gymnosperms (excluding Dicroidium). A.A. Balkema, 2: 567 p. Rotterdam.

Askin, R.A.; Charrier, R.; Hervé, F.T.; Frutos, J. 1981. Palynological investigations of Paleozoic and Lower Mesozoic Sedimentary rocks of Central Chile. Universidad de Chile, Departamento de Geología. Comunicaciones 32:10-15.

Bahlburg, H.; Breitkreuz, Ch. 1991. Paleozoic evolution of active margin basins in the southern Central Andes (northwestern Argentina and northern Chile). Journal of South American Earth Sciences 4 (3): 171-188.

Basso, M.; Marinovic, N. 2003. Antecedentes geocronológicos de volcanismo triásico en la zona de los Estratos El Bordo, Antofagasta, Chile. In Congreso Geológico Chileno No.10, Sesión temática 5. CD Rom. Concepción.

Bonetti, M.I. 1968. Las especies del género Pseudoctenis en la flora triásica de Barreal (San Juan). Ameghiniana 5: 433-446.

Breitkreuz, C. 1991. Fluvio-lacustrine sedimentation and volcanism in a Late Carboniferous tensional intra-arc basin, northern Chile. Sedimentary Geology 74 (1-4): 174-187.

Breitkreuz, C.; Helmdach, F.F.; Kohring, R.; Mosbruger, V. 1992. Late Carboniferous Intra-arc sediments in the North Chilean Andes: Stratigraphy, Paleogeography and Paleoclimate. Facies 26: 67-80.

Breitkreuz, C.; Zeil, W. 1994. The Late Carboniferous to Triassic Volcanic Belt in Northern Chile. In Tectonics of the Southern Central Andes. Structure and Evolution of an Active Continental Margin (Reutter, K.-J.; Scheuber, E.; Wigger, P.J.; editors). SpringerVerlag: $333 \mathrm{p}$.

Brüggen, J. 1942. Geología de la Puna de San Pedro de Atacama y sus formaciones de areniscas y arcillas rojas. In Congreso Panamericano de Ingeniería de Minas y Geología, Primera parte, 2: 342-367. Santiago, Chile.

Brüggen, J. 1950. Fundamentos de la Geología de Chile. Instituto Geográfico Militar: 374 p. Santiago, Chile.

Covacevich, V.; Pino, H.; Fuenzalida, G. 1988. Presencia del género Triops Shrank, 1803 (Arthropoda: Branchiopoda) en la Formación Pular (Paleozoico superior), Región de Antofagasta, Chile. In Congreso Geológico Chileno, No.5, Actas 2: 341-358. Santiago, Chile.

Charrier, R. 1979. El Triásico en Chile y regiones adyacentes de Argentina: una reconstrucción paleogeográfica y paleoclimática. Universidad de Chile, Departamento de Geología. Comunicaciones 26:1-37.

Chong, G.; Zamuner, A.B.; Lamelli-Herrera, C. 1997. Primer hallazgo de flora triásica en Quebrada Guanaqueros, Sierra de Almeida, Alta Cordillera de la Segunda Región de Antofagasta, Chile. In Simposio Argentino de Paleobotánica y Palinología, No. 10, Actas: 15. Mendoza.

Davidson, J.; Mpodozis, C.; Rivano, S. 1981.El Paleozoico de Sierra de Almeida, al oeste de Monturaqui, Alta 
Cordillera de Antofagasta, Chile. Revista Geológica de Chile 12: 3-23.

Davidson, J.; Ramírez, C.F.; Gardeweg, M.; Hervé, M.; Brook, M.; Pankhurst, R. 1985. Calderas del Paleozoico superior-Triásico inferior y mineralización asociada en la Cordillera de Domeyko, Norte de Chile. Universidad de Chile, Departamento de Geología. Comunicaciones 35: 53-57.

De Jersey, N.J.; Raine, J. 1990. Triassic and earliest Jurassic miospores from the Murihiku Supergroup, New Zealand. New Zealand Geological Survey Paleontological Bulletin 62: 1-164.

Du Toit, A. 1927. The fossil flora of the Upper Karroo beds. Part 2. Annals South African Museum 22: 289-420.

Einsele, G. 1992. Sedimentary Basins. Evolution, Facies, and Sedimentary Budget. Springer: 792 p. New York.

Gallego, O.F. 1999. Estudio sistemático de las faunas de conchóstracos triásicos de la República Argentina. Tésis doctoral (inédito). Universidad Nacional de Córdoba, Facultad de Ciencias Exactas, Físicas y Naturales: 210 p.

Gallego, O.F. 2001a. Conchostracofauna Sudamericana del Paleozoico y Mesozoico: estado actual del conocimiento. Parte 1: Argentina y Chile. Acta Geológica Leopoldensia 24 (52-53): 311-328.

Gallego, O.F. 2001b. Conchostracofauna Sudamericana del Paleozoicoy Mesozoico: estado actual del conocimiento. Parte 2: sur de Brasil (Rio Grande do Sul) y Uruguay. Acta Geológica Leopoldensia 24 (52-53): 329-337.

Gardeweg, M.; Pino, H.; Ramírez, C.F.; Davidson, J. 1994. Mapa Geológico del área de Imilac y Sierra de Almeida, Región de Antofagasta. Servicio Nacional de Geología y Minería, Documentos de Trabajo No. 7, escala 1:100.000. Santiago, Chile.

Gnaedinger, S.; Herbst, R. 1997. La Flora Triásica del Grupo El Tranquilo, Provincia de Santa Cruz, (Patagonia), Parte VII. Cycadophyta y Coniferophyta. In Simposio Argentino de Paleobotánica y Palinología, No. 10: 22. Mendoza, Argentina.

Harrington, H.J. 1961. Geology of parts of Antofagasta and Atacama provinces, northern Chile. American Association of Petroleum Geologist Bulletin 45: 169-197.

Hünicken, M.; Chaia, A. 1992. Registro de ictiolitos y fósiles asociados en la Formación Las Cabras (Triásico medio) del noroeste de Mendoza. Revista de la Asociación Geológica Argentina 47 (3): 266.

Marinovic, N.; Smoje, I.; Maksaev, V.; Hervé, M.; Mpodozis, C. 1995. Hoja Aguas Blancas, Región de Antofagasta. Servicio Nacional de Geología y Minería, Carta Geológica de Chile, escala 1:250.000, No.70: 142 p. Santiago, Chile.
Marinovic, N.; Lahsen, A. 1984. Hoja Calama, Región de Atacama. Servicio Nacional de Geología y Minería, Carta Geológica, escala 1:250.000, No. 58: 140 p. Santiago, Chile.

Miall, A.D. 1977. A review of braided river depositional environment. Earth Science Reviews 13: 1-62.

Nichols, G. 1999. Sedimentology and Stratigraphy. Blackwell: 355 p. Malden, USA.

Osorio, R.; Rivano, S. 1985. Paraparchitidae (Ostracoda) del Paleozoico superior en la Formación Pular (Harrington, 1961), Quebrada de Pajonales, vertiente occidental de la Sierra de Almeida, Antofagasta. In Congreso Geológico Chileno, No. 4, Actas 1: 439457. Antofagasta.

Pichowiak, S.; Bahlburg, H.; Breitkreuz, Ch. 1987. Paleozoic volcanic and geotectonic evolution in northern Chile. In Décimo Congreso Geológico Argentino, No. 10, Actas: 302-304.

Raczynsky, A. 1963. Geología del distrito minero de Tuina. Memoria de título (Inédito), Universidad de Chile, Departamento de Geología: 117 p.

Raymond, P.E. 1946. The genera of fossil Conchostraca: an order of bivalved Crustacea. Museum of Comparative Zoology Bulletin 96: 218-307. Harvard University.

Reineck, H.E.; Singh, I.B. 1980. Depositional Sedimentary Environments. Springer Verlag: 549 p. Berlin.

Salinas, P.; Sepúlveda, P.; Marshall, L. 1991. Hallazgo de restos óseos de dinosaurios (Saurópodos) en la Formación Pajonales (Cretácico Superior), Sierra de Almeida, Región de Antofagasta, Chile: Implicancia Cronológica. In Congreso Geológico Chileno, No. 6, Actas: 534-537. Santiago.

Smoje, I.; Marinovic, N. 1994. Intrusivos del Carbonífero-Pérmico en la Cordillera de Domeyko: nuevos antecedentes radiométricos. In Congreso Geológico Chileno, No. 7, Actas 2: 1213-1216. Concepción.

Wood, G.D.; Palmer-Koleman, S.E.; Alemán, A.M.; Padilla,H. 2002. Palynofacies and biomarker analysis of the lowermost Permo-Carboniferous Pular Formation, a volcanic arc sequence in the Sierra de Almeida, Northern Chile. Review of Palaeobotany and Palynology 118: 323-333.

Zavattieri, A.M.; Batten, D.J. 1996. Miospores from Argentinian Triassic deposits and their potential for intercontinental correlation. In Palynology: principles and applications (Jansonius, J.; McGregor, D.C.; editors). American Association of Stratigraphic Palynologists Foundation, Chapter 20B, 2: 767-778.

Zavattieri, A.M.; Herbst, R.; Muñoz Bravo, J. 2003. Microflora de la Formación Panguipulli (Triásico Superior), en Licán Ray, Lago Calafquén, X Región, Chile. Ameghiniana 40 (4): 585-600. 


\section{PLATES 1-2}




\begin{abstract}
APPENDIX
Palynologic slides are stored in the collections of the Paleopalynology Unit of IANIGLA/CRICYT (CONICET) in Mendoza, Argentina under numbers 7946-7950 and 8142-8170. The macroflora is housed in the Paleobotanical Collection of the Museo de Ciencias Naturales de La Plata, Argentina and Universidad Nacional de La Plata, Argentina (LPPb) No. 13241. The repository of the conchostracans is housed in the Paleozoological Collection, Facultad de Ciencias Exactas y Naturales y Agrimensura, Universidad Nacional del Nordeste, Corrientes, Argentina (CTES-PZ) No. 7356 to 7360. The repository of calcareous microfauna is housed in the Museo de Ciencias Naturales de La Plata, Argentina (sección Micropaleontología), No. MLP-Mi 1546-1572.
\end{abstract}

PLATE 1

Palynomorphs of the Pular Formation. All figures approximately x750.

Figures

Deltoidospora sp. 8146A.

$\mathrm{b}$

cf. Granulatisporites sp. 8142C.

c

Gleicheniidites sp. 8142D.

d

cf. Alisporites parvus de Jersey, 7948C.

e

cf. Pinuspollenites sp. 8167A.

f

Alisporites sp. cf. A. lowoodensis de Jersey, 8142C.

g

Alisporites sp. cf. A. australis de Jersey, 7948D.

$\mathrm{h}$

cf. Klausipollenites sp. 8142C.

Equisetosporites sp. cf. E. cacheutensis Jain, 8144A. 

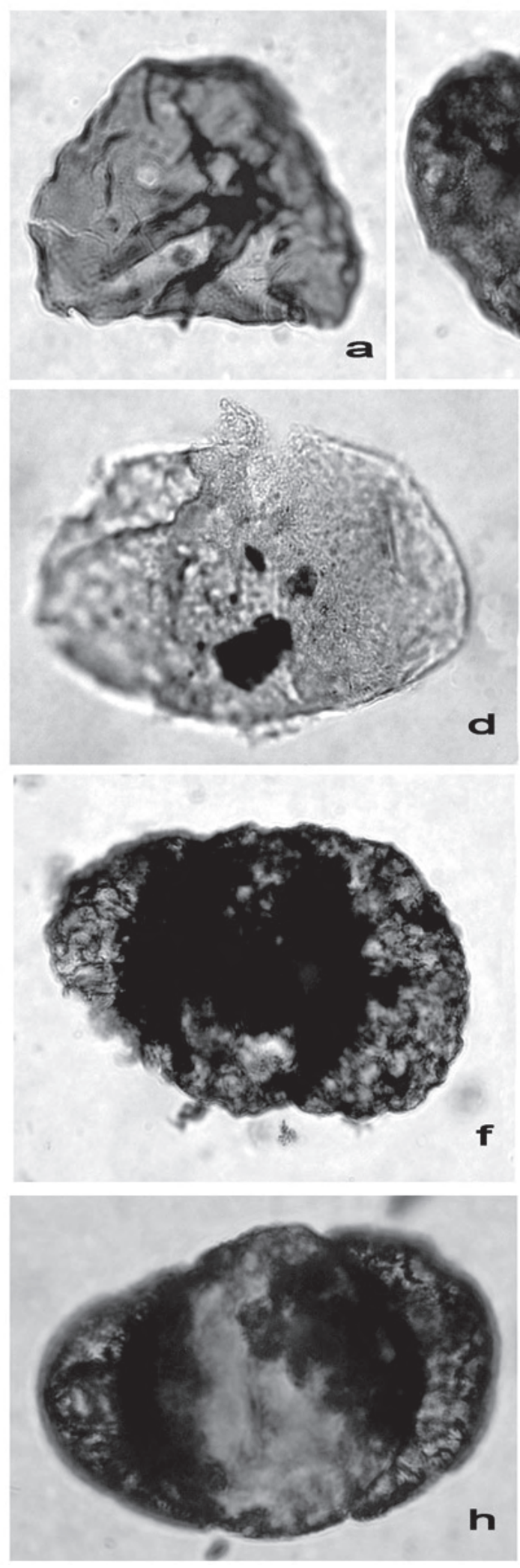
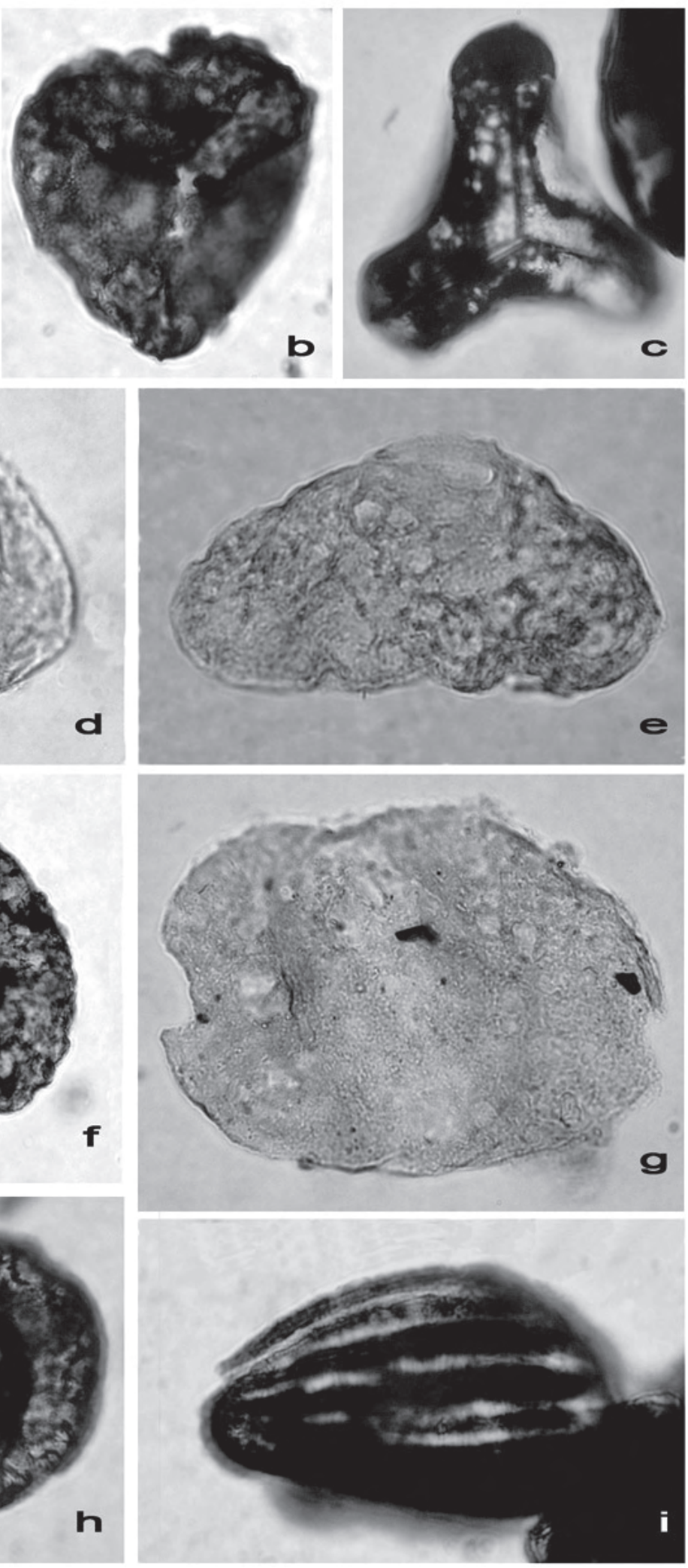
PLATE 2

Macroflora and conchostracans of the Pular Formation.

\section{Figures}

b. Subcircular left valve, scale bar $1 \mathrm{~mm}$, CTES-PZ 7357.

c. Ovate right valve, scale bar $1 \mathrm{~mm}, \mathrm{CTES}-\mathrm{PZ} 7356$.

d-e. Details of the irregular areolar ornamentation between growth lines (scanning electronic micrographs), scale bar $0.5 \mathrm{~mm}$, CTES-PZ 7360. 

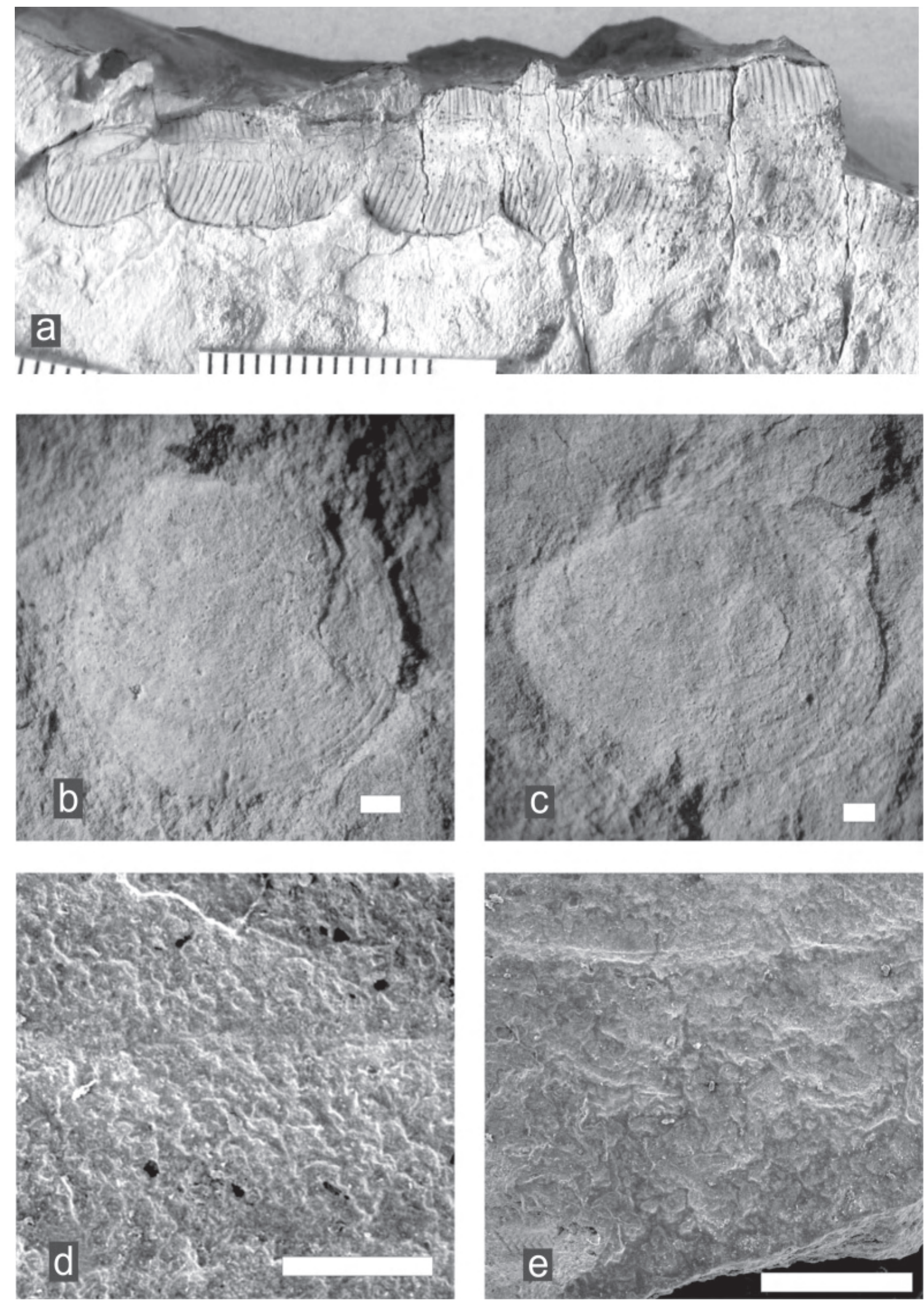